This item was submitted to Loughborough's Research Repository by the author.

Items in Figshare are protected by copyright, with all rights reserved, unless otherwise indicated.

\title{
A methodology for best practice knowledge management
}

PLEASE CITE THE PUBLISHED VERSION

PUBLISHER

Professional Engineering Publishing / @ IMechE

VERSION

VoR (Version of Record)

LICENCE

CC BY-NC-ND 4.0

REPOSITORY RECORD

Dani, Shilpa S., Jennifer A. Harding, Keith Case, R.I.M. Young, Sean D. Cochrane, James Gao, and David Baxter. 2019. "A Methodology for Best Practice Knowledge Management". figshare. https://hdl.handle.net/2134/4677. 
This item was submitted to Loughborough's Institutional Repository (https://dspace.lboro.ac.uk/) by the author and is made available under the following Creative Commons Licence conditions.

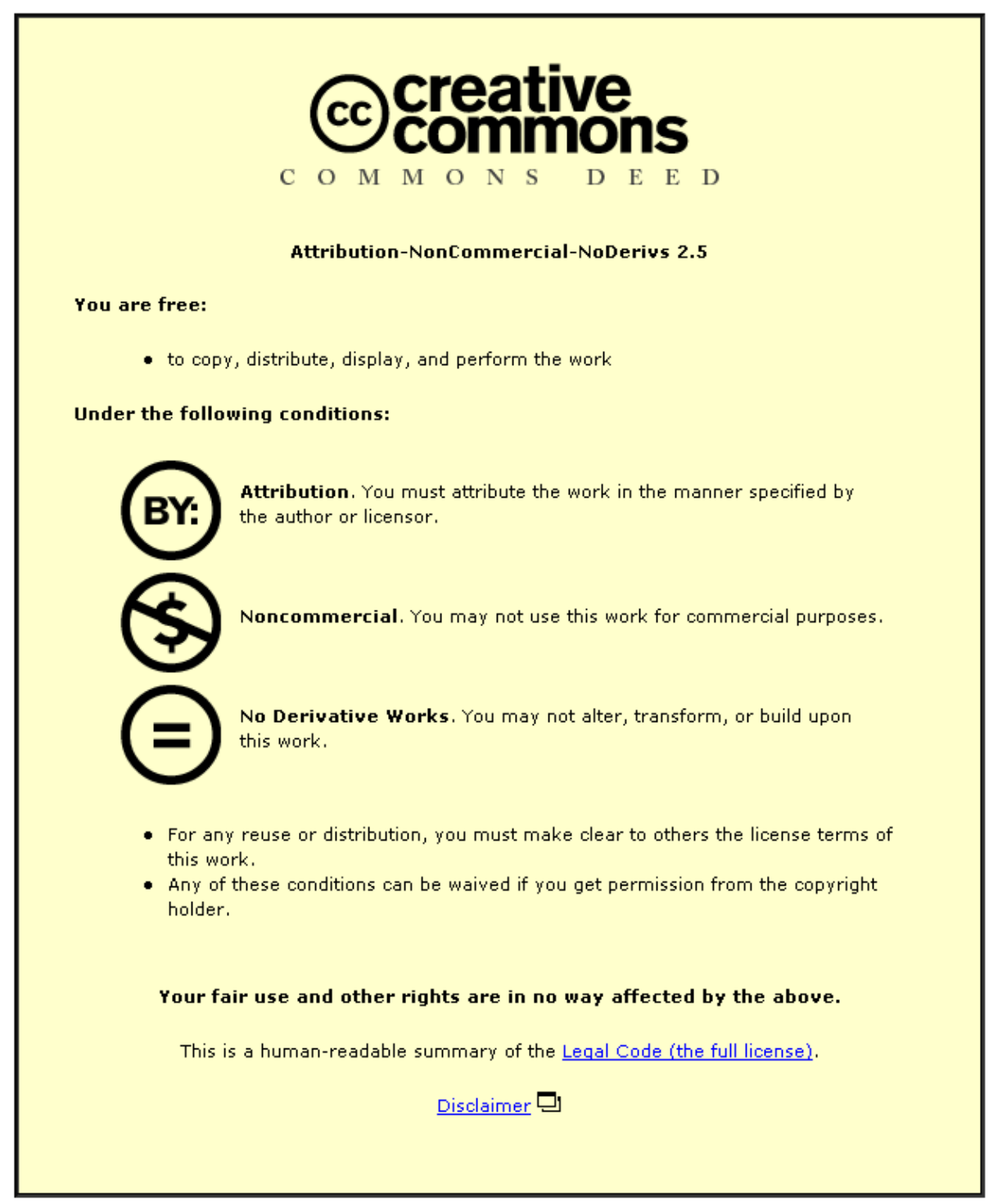

For the full text of this licence, please go to: http://creativecommons.org/licenses/by-nc-nd/2.5/ 


\title{
A methodology for best practice knowledge management
}

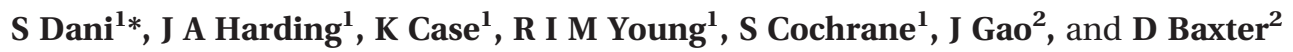 \\ ${ }^{1}$ Wolfson School of Mechanical and Manufacturing Engineering, Loughborough University, Loughborough, UK \\ ${ }^{2}$ Enterprise Integration, Cranfield University, Cranfield, UK
}

The manuscript was received on 18 May 2006 and was accepted after revision for publication on 27 June 2006.

DOI: 10.1243/09544054JEM651

\begin{abstract}
Capturing and reusing knowledge of best practices has been identified as one of the requirements for next-generation product development. Knowledge identification is therefore already being done to some degree in many organizations, through instruction manuals or 'how to' guidelines. However, this is only a first step, as to fully exploit valuable knowledge, best practices must be identified and shared. A detailed review of previous research in best practice knowledge management shows that the method of modelling best practice knowledge and the resulting model structure are critically important for the successful reuse of best practice knowledge. Yet, to date, only limited research has been focused on these aspects. This paper therefore presents research into a methodology to determine ways for better communication, sharing, and reuse of best/good practice knowledge. The proposed methodology has been divided into two parts: firstly, the identification of best practices for product development, and secondly, the structuring of best practice knowledge for effective sharing and reuse. This methodology encourages the adoption of best practices by providing knowledge about both process and implementation elements. This makes the explicit knowledge easier to find and reuse. Once a best practice is found to suit current requirements and circumstances, an expert who has identified and used the best practice can also be contacted to gain additional knowledge/information. This helps to address the challenges posed by 'tacit' knowledge, which cannot easily be shared within the knowledge base.
\end{abstract}

Keywords: product development, best practices, knowledge management, knowledge reuse

\section{INTRODUCTION}

The economic success of manufacturing firms depends on their ability to identify the needs of customers and to produce quickly products that meet these needs at low cost. Achieving these goals is not solely a marketing problem, nor a design problem, nor a manufacturing problem; it is a product development problem involving all these functions [1]. Product design and development is information and knowledge-intensive work and some of this is exploitable for multiple projects or across different product ranges. Yet, knowledge is often generated within one project and then

\footnotetext{
${ }^{*}$ Corresponding author: Wolfson School of Mechanical and Manufacturing Engineering, Loughborough University, Loughborough, Leicestershire LE11 3TU, UK. email: S.Dani3@ lboro.ac.uk
}

buried in unread reports and arcane filing systems, or lost because people move on [2]. Competitive advantage can be gained through a company's superior product development capabilities, which derive from its ability to create, distribute, and utilize knowledge throughout the product development process [3-7]. Failure to capture and transfer this knowledge leads to an increased risk of 'reinventing the wheel', wasted activity, and impaired project performance [8]. Identification of knowledge and processes that are common or might be shared is often one of the first tasks undertaken in a knowledge management initiative. Knowledge identification is therefore already being done to some degree in many organizations, through instruction manuals or 'how to' guidelines. However, this is only a first step; in order to fully exploit valuable knowledge, best practices must be identified and shared. 
Identifying and sharing knowledge of best practices has been established as one of the requirements for next-generation product development [9]. Best practice transfer has therefore become the business imperative of both original equipment manufacturers (OEMs) and the small and mediumsized enterprises (SMEs) [10]. Best practices must be learnt from others, but managing such information and knowledge transfer is a critical challenge facing modern-day organizations. Such best practice knowledge will be explicit and documented, but in many cases such knowledge will be tacit - held in people's heads and difficult to document. Therefore, best practice programmes need to combine two key elements:

(a) to build explicit knowledge into a best practice knowledge base which connects people with information;

(b) to provide methods for sharing tacit knowledge such as communities of practice that can connect people with people.

These two approaches are complementary and are both essential.

This paper presents research into a methodology to determine ways for better communication, sharing, and reuse of best/good practice knowledge. A detailed review of previous research in this area shows that the method of modelling best practice knowledge and the resulting model structure is critically important for the successful reuse of best practice knowledge. To date, only limited research has been focused on these aspects. The proposed methodology, therefore, has been divided into two parts: firstly, the identification of best practices for product development, and secondly, the structuring of best practice knowledge for effective sharing and reuse.

\section{RESEARCH CONTEXT}

The research method adopted was to develop and validate a conceptual methodology for best practice transfer process using data obtained from case studies. The conceptual best practice methodology was developed using concepts studied from various sources of literature, as described in sections 2 and 3. In order to validate the methodology, it was important to apply it in an industrial setting. As the work is still ongoing, validation has been possible only on a small scale. The application of the methodology at one of the collaborator companies is represented in this paper. One of the most important issues in the development of the conceptual methodology was to determine an operational definition of a 'best practice' and role of knowledge management in best practice transfer process. 'Best practice' is a very popular and commonly used term in industry but its meaning is often assumed rather than clearly defined.

\subsection{Best practice definitions}

Best practices may be described as optimum ways of performing work to achieve high performance [11, 12]. The International Quality Study [13] defines best practices as those that have aided the lowerperforming organizations to improve to medium performance, medium performers to improve to higher performers, and higher performers to stay on top and achieve further benefits. A best practice is a practice that will lead to the superior performance of a company $[\mathbf{1 4}, \mathbf{1 5}]$. Heibeler et al. [16] describe best practices as 'the best ways to perform a business process'. Hughes and Smart [17] propose a more detailed definition of best practice as 'an activity or action which is performed to a standard that is better or equal to the standard achieved by other companies in circumstances that are sufficiently similar to make meaningful comparison possible'. The American Productivity and Quality Center [18] noted that although there is no single 'best practice' because best is not best for everyone, what is meant by 'best' are 'those practices that have been shown to produce superior results; selected by a systematic process; and judged as exemplary, good, or successfully demonstrated'. The Chevron approach categorizes the practices as: good idea (unproven), good practice (satisfying some element of customers' and stakeholders' needs), and 'proven' best practice [19]. The proposed methodology has taken a similar approach such that any process or practice can be categorized as a poor (low performance), good, or best practice.

\subsection{Why best practices?}

Just as there are many different definitions of best practice, current literature provides a variety of ways in which best practice can be transferred within an organization or between organizations. Table 1 provides a summary of some of the methodologies for the transfer of best manufacturing practices. The transfer of best practices is crucially important because it really is a powerful tool to help companies achieve valuable productivity and competitiveness gains [10]. The benefit of best practice transfer is to achieve quantum leap changes without reinventing the wheel. As economy grows, transfer and reuse of the best practices will enable growth without adding undue costs. No matter the industry, reusing successfully demonstrated practices can lead to shorter cycle times, faster rampup, higher customer satisfaction, better decisions, 
Table 1 A summary of best practice methodologies

\begin{tabular}{|c|c|c|c|}
\hline & Best practice definition & Best practice transfer steps & Result \\
\hline $\begin{array}{l}\text { Texas Instruments [14] } \\
\text { Business excellence }\end{array}$ & A practice that is best for me. & $\begin{array}{l}\text { 1. Define business excellence } \\
\text { for business. } \\
\text { 2. Assess the progress. } \\
\text { 3. Identify improvement } \\
\text { opportunities. } \\
\text { 4. Establish and deploy } \\
\text { an action plan. }\end{array}$ & $\begin{array}{l}\text { Process improvement, } \\
\text { knowledge-sharing }\end{array}$ \\
\hline $\begin{array}{l}\text { [19] Total quality } \\
\text { management }\end{array}$ & $\begin{array}{l}\text { Those practices that have been shown } \\
\text { to produce superior results; selected } \\
\text { by a systematic process; and judged } \\
\text { as exemplary, good, or successfully } \\
\text { demonstrated. }\end{array}$ & $\begin{array}{l}\text { 1. Search. } \\
\text { 2. Evaluate. } \\
\text { 3. Validate. } \\
\text { 4. Implement. } \\
\text { 5. Review. } \\
\text { 6. Routinize. }\end{array}$ & Benchmarking \\
\hline $\begin{array}{l}\text { Royal Mail [21] Quality } \\
\text { improvement in postal } \\
\text { services }\end{array}$ & $\begin{array}{l}\text { Any proven working practice that is } \\
\text { far enough ahead of the norm to } \\
\text { provide significant performance } \\
\text { gain if implemented. }\end{array}$ & $\begin{array}{l}\text { 1. Identify good } \\
\text { practice. } \\
\text { 2. Evaluate. } \\
\text { 3. Categorize as 'mandatory' } \\
\text { or 'recommended'. } \\
\text { 4. Adopt/implement. } \\
\text { 5. Communicate in all } \\
\text { relevant units. } \\
\text { 6. Review for further } \\
\text { implementation. }\end{array}$ & $\begin{array}{l}\text { Process improvement, } \\
\text { knowledge-sharing }\end{array}$ \\
\hline $\begin{array}{l}\text { [23] Manufacturing } \\
\text { planning and control }\end{array}$ & & $\begin{array}{l}\text { 1. Identify need for } \\
\text { improvement. } \\
\text { 2. Identify best practices in } \\
\text { the relevant area. } \\
\text { 3. Prioritize the best practices. } \\
\text { 4. Assess the predecessor } \\
\text { practices. } \\
\text { 5. Implement desired practice. }\end{array}$ & $\begin{array}{l}\text { Improvement in operational } \\
\text { performance }\end{array}$ \\
\hline $\begin{array}{l}\text { Nationwide Building } \\
\text { Society [22] Business } \\
\text { excellence in financial } \\
\text { services }\end{array}$ & $\begin{array}{l}\text { A task, function, or behaviour } \\
\text { that, when carried out, } \\
\text { produces above-average results. }\end{array}$ & $\begin{array}{l}\text { 1. Identify key business } \\
\text { processes. } \\
\text { 2. Define main elements } \\
\text { of each process. } \\
\text { 3. Identify practitioner for } \\
\text { each element. } \\
\text { 4. Extract and codify best } \\
\text { practice for each element. } \\
\text { 5. Synthesize best practice. } \\
\text { 6. Improve or implement. } \\
\text { 7. Review. }\end{array}$ & Performance improvement \\
\hline
\end{tabular}

and lower costs $[\mathbf{2 0}]$. Some of the benefits of sharing best practices from the literature review can be summarized as follows $[\mathbf{1 4}, \mathbf{1 9}, \mathbf{2 1 - 2 3 ]}$ :

(a) identify and replace poor practices;

(b) improve process performance;

(c) avoid reinventing the wheel;

(d) minimize rework caused by use of poor methods;

(e) save costs through better productivity and efficiency.

\subsection{Managing best practice knowledge}

According to reference [22], companies that apply the transfer of best practices need to appreciate that the real benefit from new knowledge is not only to close gaps in performance but also to build capability and enrich the knowledge base, which is even more critical for sustaining long-term competitive advantage. This was also verified by Bartlett and Ghoshal [24]. Process improvement through the transfer of best practices should affect not only the 
processes themselves but also the knowledge needed for the process, and the configuration of this knowledge alongside the process. Thus, it is important to identify the best practices in a particular organization but at the same time it is vital to have knowledge of the environment in which the practice is 'best'. Literature related to the best practice transfer process shows that most of the best practice methodologies available today focus only on the identification of the best practices $[\mathbf{1 4}, \mathbf{1 9}, \mathbf{2 1 - 2 3}, \mathbf{2 5}]$. Very few methodologies address the knowledge management issues. As mentioned in section 1 the structure of the best practice knowledge base plays a very important role in the process of sharing and reusing of the best practice knowledge and therefore should be studied in more detail.

\section{DEVELOPING THE BEST PRACTICE METHODOLOGY}

The authors' research addresses the above issues through a two-step methodology for identifying and sharing best practice knowledge. The methodology proposes an additional stage of best practice knowledge base creation to the current best practice methodologies which addresses a gap identified in the reported literature (Fig. 1). Best-practices (or leading practices) knowledge bases provide access to enterprise processes that appear to define the best ways of doing things [26]. A best practice is simply a process or a methodology that represents the most effective way of achieving a specific objective. It should be noted that 'best' is a moving target in today's world, and it is also situation-specific. Thus, it is important to identify the best practices in a particular organization but at the same time it is vital to have knowledge of the environment in which the practice is 'best'. A knowledge base in this case provides information about the best practice itself, as well as the implementation elements. This makes the explicit knowledge easier to find and reuse. A potential user can find the best practice and decide if it is worth pursuing further (to suit his/her requirements and circumstances). An expert who has identified and used the best practice can also be contacted to gain additional knowledge/informainformation. This helps to address the challenges posed by 'tacit' knowledge, which cannot easily be shared within the knowledge base. The additional stage of creating and sharing a best practice knowledge base delivers value to the organization in two fundamental ways:

(a) by transferring the 'best practice information' available anywhere in the organization directly to the point of need in order to promote the 'best thinking possible';

(b) by helping the organization to learn earlier and more creatively than the competition in order to develop a sustainable edge.

There are many ways of adopting best practices, including the well-established technique of benchmarking. The most common definition of benchmarking is by Robert Camp [15]: 'Benchmarking is the search for best industry practices that will lead to superior performance'. Benchmarking is a means of improving business or organizational performance. Davis and Kochhar [27] strongly argue that, to be truly effective, benchmarking needs to be devolved to other contributing levels within a business. Benefits that can be derived from such action are that performance measures and associated targets for strategic objectives can be devolved throughout the organization and focused on the areas that can satisfy them. Best practices can then be identified and applied to improve performance in these areas. The proposed methodology (see Fig. 2) involves the establishment of a list of best practices and measures of performance against which companies are measured, for which exact knowledge of company objectives is necessary.

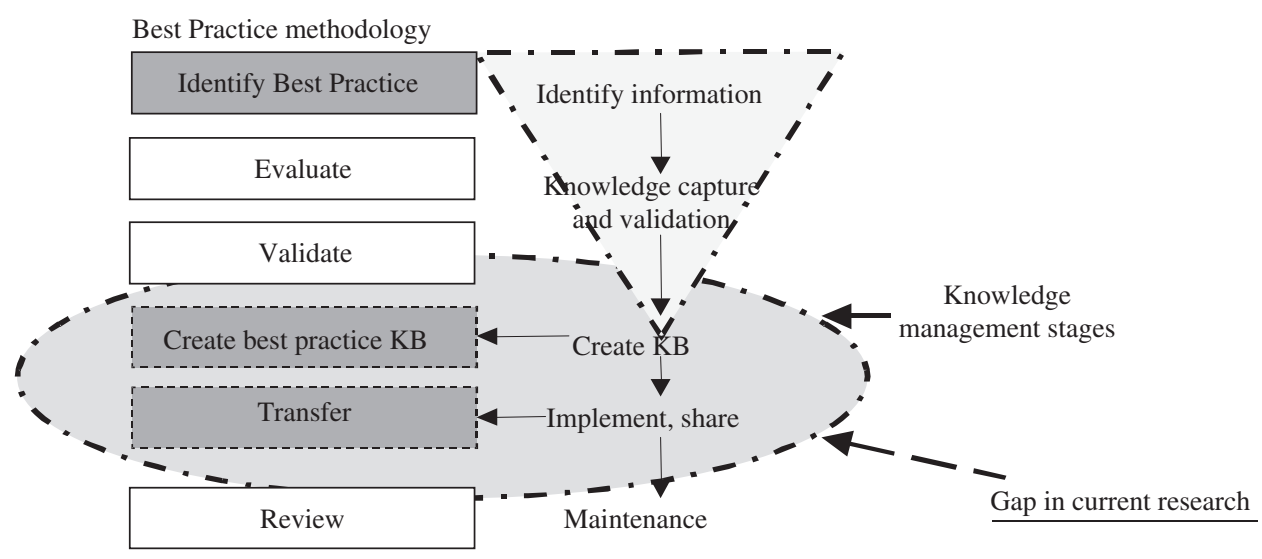

Fig. 1 Best practice knowledge management 


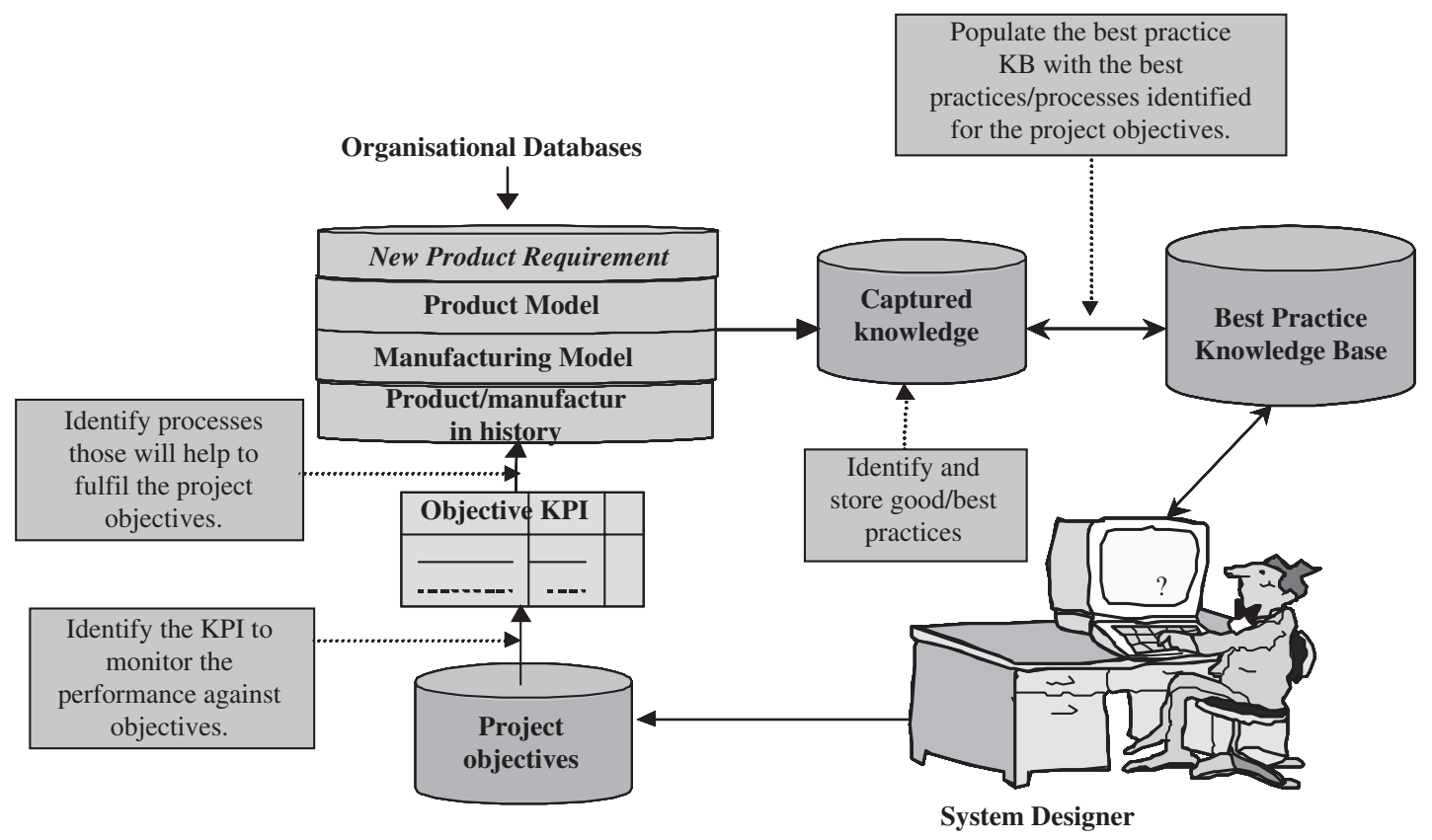

Fig. 2 Methodology for identification and storage of best practice knowledge

\subsection{The methodology}

\subsubsection{Identify project objectives}

Clear and explicit project objectives are essential to the success of any project. However, the identification of such objectives is not a part of the methodology for identification and sharing of best practice knowledge; rather, the methodology assumes that such objectives have previously been identified and are therefore accessible.

\subsubsection{Identify key performance indicators (KPIs)}

As explained in the earlier sections the success and continuity of an organization depend on its performance, which may be defined as 'the way the organization carries its objectives into effect' [8]. An important first step is to identify what the company should measure and how. The performance indicators (PIs) are important for everyone inside an organization, as they tell what has to be measured and what are the control limits the actual performance should be within [8]. PIs are the qualitative indicators that show how well the organization's objectives are being met whereas key performance indicators (KPIs) are the performance measures critical to an organization's core business [28]. KPIs are identified at the beginning of the project and according to Keegan should include the following criteria.

1. Specify the goals - What are we trying to achieve?

2. Match the measures to strategic intent - What is most important?

3. Identify the measures - What should we measure?
4. Predicting the results - What will change?

5. Building commitment - Who should get on board?

6. Planning the next step - Where do we go from here?

\subsubsection{Identify good/best practices}

Once the KPIs for the project have been decided the existing processes can be checked against the objectives of the project of the KPIs. Practices are then prioritized in terms of the strongest positive relationships with the measure, taking into account any negative side effects that exist (Fig. 3). For each prioritized practice, assessment takes the place of the practices that are necessary to support implementation. These are the practices that must be in place to support the desired practice and to enable performance improvement to take place.

A questionnaire is designed to collect information about the performance of the existing processes against objectives of the project. The data collected are divided into three categories: good/best processes, implementation elements, and lessons learnt in the past projects. Knowledge about the implementation elements and the lessons learnt elements together with the supporting processes can be used to identify the best practices and also to identify the factors that can be changed to make a particular process better or best. The data/information collected about the best processes can then be stored in the 'best practice knowledge base' for future reuse. 


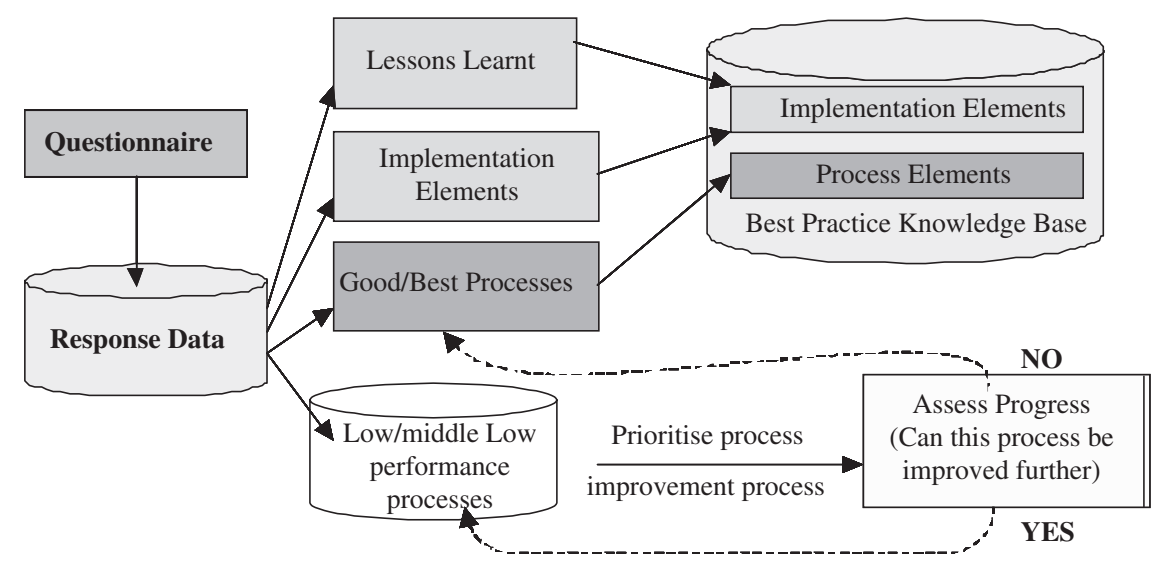

Fig. 3 Identification and formulation of best practices

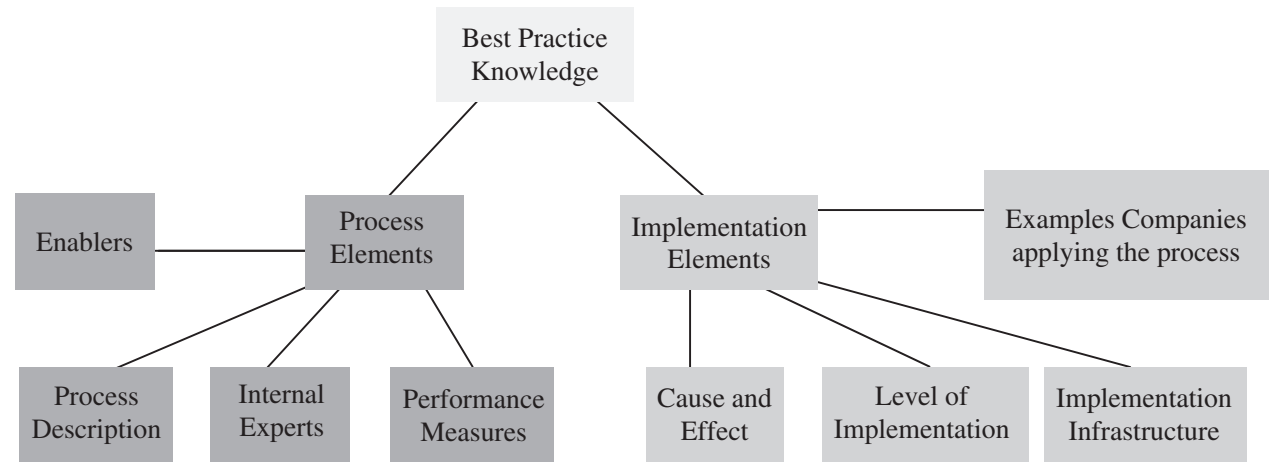

Fig. 4 Best practice knowledge classification

\subsubsection{Populating the best practice knowledge base}

A key consideration at this stage is how to organize and classify the information in the best practice knowledge base so that users can readily find what they need. The information collected about the best practices is classified in the following two broad categories: process elements and implementation elements. Figure 4 shows the best practice knowledge classification, whereas the detailed class structure is depicted in Fig. 5.

(a) Process elements - Knowledge required about the best practices.

1. Process specific knowledge: this includes the process flow diagram and knowledge about the human and machine resources, output of the process, and the subprocesses involved.

2. Performance measures knowledge: focuses on performance results in terms of quality, cost, and time measures. (Which metrics can be applied to the measurement of the best practices?) It is necessary to investigate which practices improve which areas of performance in order that guidance can be given to improve specific areas of performance. In this case, metrics for the performance measurement are important.

3. Enablers knowledge: knowledge about any processes and tools or techniques that are supporting the practice and enabling it to be a best practice.

4. Internal experts knowledge: this is stored to improve communication as the expert can then be contacted for more information on a best practice. This type of knowledge is particularly important as it supplements the explicit knowledge stored in the knowledge base with valuable tacit knowledge, by facilitating person-to-person communication.

(b) Implementation elements - Knowledge required for implementing the best practices. The vast majority of current literature is limited to the dissemination of best practice, without discussing in detail the necessary background to the particular best practice. Background knowledge of the best practice(s) and situations in which they have successfully been implemented would help companies to determine whether a best practice is appropriate for their current environment. It could also help to determine when an existing best practice might be exploited or possibly adapted for a new context. 


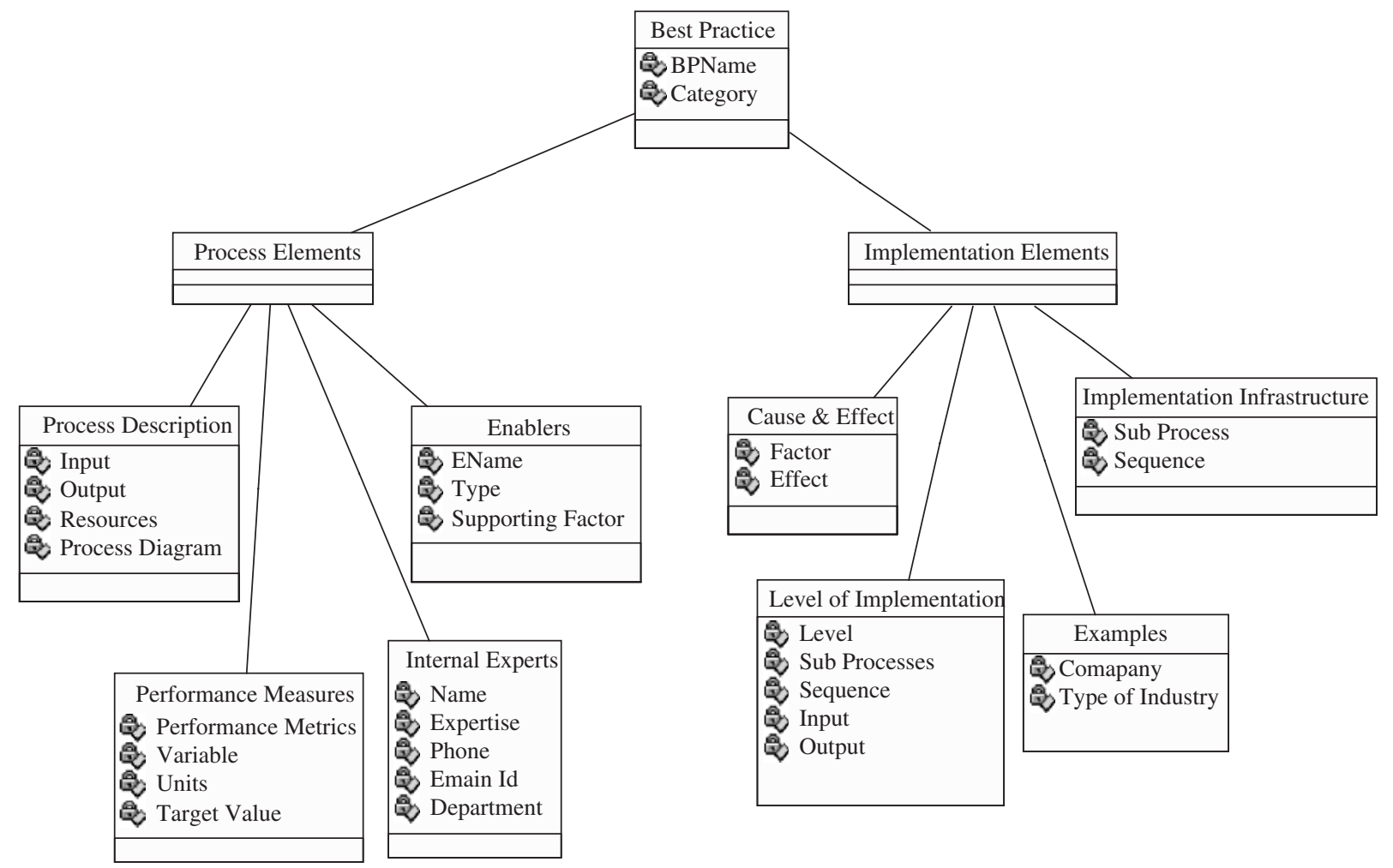

Fig. 5 Best practice class structure

1. Cause-effect relationship knowledge: implementation of practices in isolation of measures fails to take into consideration cause and effect relationships. Implementation of a practice may improve the performance in one area but have adverse effects on another process, affecting the overall performance. Thus, there is a need to determine which best practices to use to improve specific areas of performance, in addition to analysing any detrimental effects on other areas of performance

2. 'Level of implementation' knowledge: whether a practice is fully in place or partially implemented will affect the potential performance benefits.

3. Implementation infrastructure knowledge: literature indicates that there is an infrastructure of practices and a maturity phase for practices, thus indicating that there is a sequence in which practices should be implemented.

4. Examples of companies applying the best practice: this section of the knowledge provides examples of the experiences of a specific company that has implemented a leading practice. It may be structured in different ways to meet the needs of particular organizations; for example, Ernst and Young divided their best practice knowledge base into eight categories: executive processes, finance, new business development, knowledge management, order management, production and service delivery, supply chain management, support and shared services. Alternatively, the knowledge base can be viewed from an industrial perspective: automotive, energy, finance services, health care, insurance, life science, manufacturing, retail, service, transportation.

\section{APPLICATION OF THE PROPOSED BEST PRACTICE METHODOLOGY}

This section illustrates the use of the proposed methodology through an industrial case study example. Because of the nature of the business and issues of confidentiality, the company is not named here and the case study material has been modified in places. However, great care has been taken to ensure that the following example provides an accurate representation and demonstration of the proposed methodology in an industrial context. The implementation of the best practice methodology is demonstrated and problems and research results are illustrated.

The company is part of an international group and they manufacture many types of product and component at different manufacturing sites located globally. The manufactured components are then transported from different sites for assembly at 


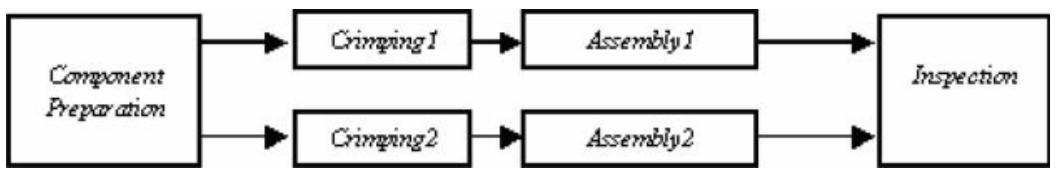

Fig. 6 Full production line

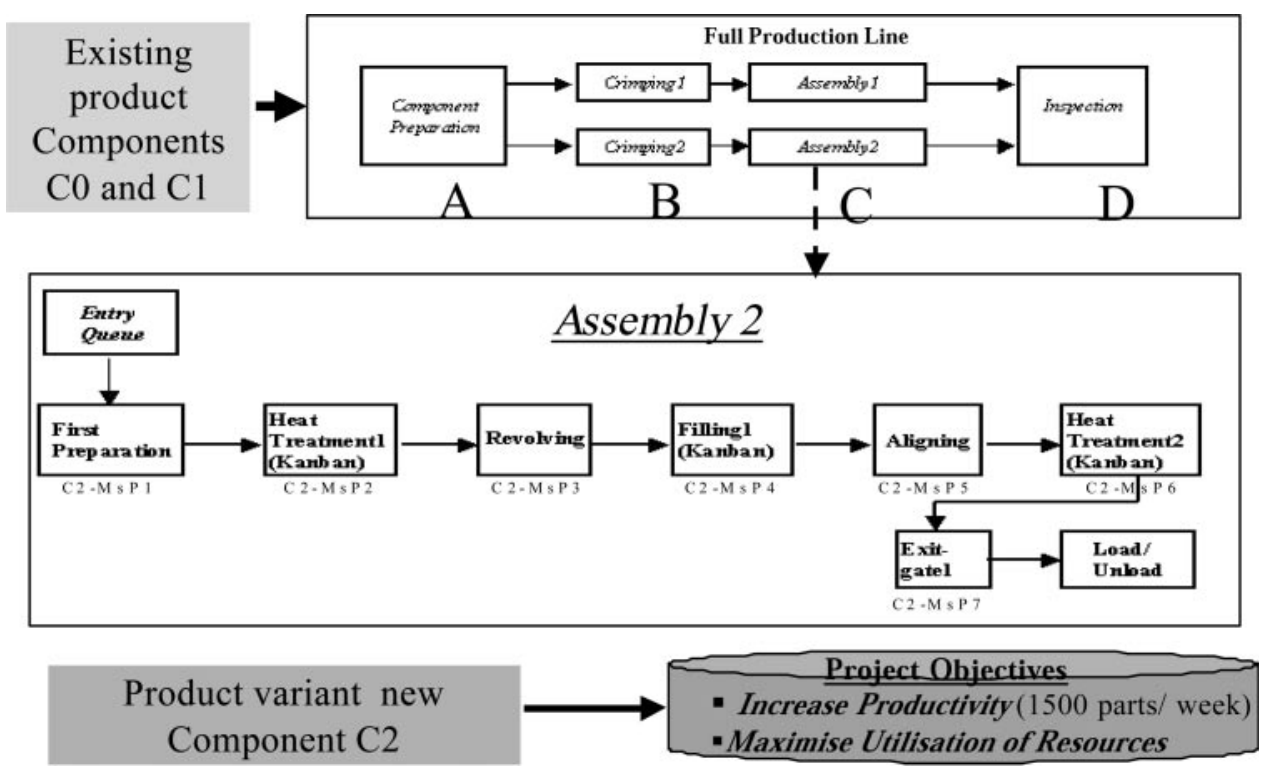

Fig. 7 Outline of the example

facilities managed by the company. The company currently manufactures a range of products, which will be referred to here as $\mathrm{P} x$. Different variants of this product are also planned, and individual types will be referred to as P1, P2, and P3 in this study.

At one point of their manufacture, products from the range P $x$ pass through four main processes: component preparation, crimping, assembly, and inspection, as shown in Fig. 6 below. Two existing products from this range are $\mathrm{P} 1$ and $\mathrm{P} 2$.

Currently, the product development process is underway for a new product variant P3 that is slightly different from existing products $\mathrm{P} 1$ and $\mathrm{P} 2$. For this new project the main and clear business objectives of the company are:

(a) to increase manufacturing capability to over 1500 products per week in order to make the factory product production line economically viable;

(b) to make more efficient use of manufacturing and human resources (see Fig. 7).

For clarity, this case study example focuses only on the selection of the assembly process for P3. In current production, the assembly process can be performed by any of three different processes, which are carried out in two different cells, identified as Assembly 1 and Assembly 2. Assembly 1 and Assembly 2 work independently from each other and have completely different sets of machinery and operators, yet undertake exactly the same tasks. The human operators for each cell are named as C1-HR1, C1-HR2 or C2-HR1, C2-HR2, etc., and the machines as C1-MR1, C1-MR2, C1-MR3, etc.

The three different versions of the assembly are as follows.

\section{Process_Ver1}

Resources: machines C1-MR1, C1-MR2, C1-MR3.

Human resources: C1-HR1.

Output: product P1.

Contains: subprocesses C1-MsP1-MsP7.

\section{Process_Ver2}

Resources: machines C1-MR1, C1-MR2, C1-MR3.

Human resources: C1-HR1, C1-HR2.

Output: product P1.

\section{Process_Ver3}

Resources: machines C2-MR1, C2-MR2, C2-MR3.

Human resources: C2-HR1, C2-HR2.

Output: product P2.

\subsection{Identify KPIs}

In the current project the main objectives are to increase the production capability and to make more efficient use of the manufacturing and human 
Table 2 Comparison of the performance measures for three possible options

\begin{tabular}{lllll}
\hline & $\begin{array}{l}\text { Total } \\
\text { throughput }\end{array}$ & $\begin{array}{l}\text { C2-HR1 } \\
\text { busy (\%) }\end{array}$ & $\begin{array}{l}\text { C2-HR1 } \\
\text { busy (\%) }\end{array}$ & $\begin{array}{l}\text { C2-MR3 } \\
\text { busy (\%) }\end{array}$ \\
\hline Process_Ver1 & 1340 & 79.43 & - & 56.93 \\
Process_Ver2 & 1552 & 50.58 & 50.32 & 62.97 \\
Process_Ver3 & 1632 & 48.10 & 47.79 & 59.76 \\
\hline
\end{tabular}

resources. In order to measure the effectiveness of the product development process (by incorporating the best practices and processes) and predict the programme and product performance, the process metrics for the product development process are most suitable [29]. The process metrics are:

(a) staffing versus plan;

(b) turnover rate;

(c) errors per 1000 products.

Therefore, in the present case study example, the nearest available measures to these are considered; these are the output of the manufacturing (total throughput) and human resources (percentage utilization of staff) for each of the three versions of the assembly process (see Table 2).

\subsection{Identify good/best practices}

From the available information about the three versions of assembly process and Table 2, it is clear that the results from Process_Verl are not ideal. There is only one human resource, C1-HR1, who has to undertake several different activities, including needing to keep three machines loaded and needing to work almost continuously. Presently the average utilization of the operator is 79.43 per cent. However, Process_Verl is termed as a low-performing process in terms of total throughput and lowest utilization rates of the production machinery. In contrast, Process_Ver2 and Process_Ver3 are the two processes judged to have delivered good results in the past, with good total throughput results and good utilization rates for the production machinery. The production experts therefore recommended these as the good processes. These two processes were identified from the performance data and expert recommendations and were therefore stored in the best practice knowledge base as the current best practices.

\subsection{Populating the best practice database}

Once the best practices have been identified, the best practice information is stored in the best practice knowledge base. The Process_Ver2 and Process_Ver3 were identified as the good practices. The knowledge about these practices was then stored in the best practice knowledge base. As explained in the previous sections the process information is divided into two categories: process elements (see Fig. 8) and implementation element (see Fig. 9). This section demonstrates how the information is stored using Process_Ver3 data.

\subsection{Selecting best practice for a new project}

Previous sections have explained how best practices can be identified and how the knowledge about these practices can be stored in the best practice knowledge base for sharing and future reuse. This section explains how a best practice can be selected for a new project. As explained earlier, a new product version P3 is under construction. From the above information there are two possible best processes that can be selected for assembly. From the knowledge about the process elements, both the processes Process_Ver2 and Process_Ver3 meet current project objectives (over 1500 products per week and efficient use of manufacturing and human resources). Throughput of Process_Ver3 is more than that of Process_Ver2 and also it is more efficient in use of the resources, which makes it the better of the two available processes. Once the best suitable process is selected the implementation elements (from the best practice database) provide the necessary details in order to achieve maximum benefits from the new best practice implementation. For example, reference to the enabler knowledge elements indicates that training related to ongoing prioritization of tasks will be critical to the success of transferring this best practice information into the implementation of a new assembly process for P3. Further study of the implementation elements, and in this case, particularly of the cause and effect relationship knowledge, indicates to the managers designing the new production system for P3 how critical prioritization of tasks has been achieved in the existing assembly processes. The new managers are therefore made aware of the value of reusing these approaches for P3. It is therefore made easier to reuse, transfer, and modify existing 'best practice' from P1 and P2 to P3 (see Fig. 10).

\section{DISCUSSION}

A significant percentage of recent literature in the areas of business and manufacturing makes reference to 'best' practices. A number of companies have launched initiatives to share their best ideas and management practices. From the literature reviewed, the following conclusions can be drawn.

1. Common-sense 'good practices' are often not communicated to and within companies in a way that is understandable and usable. 


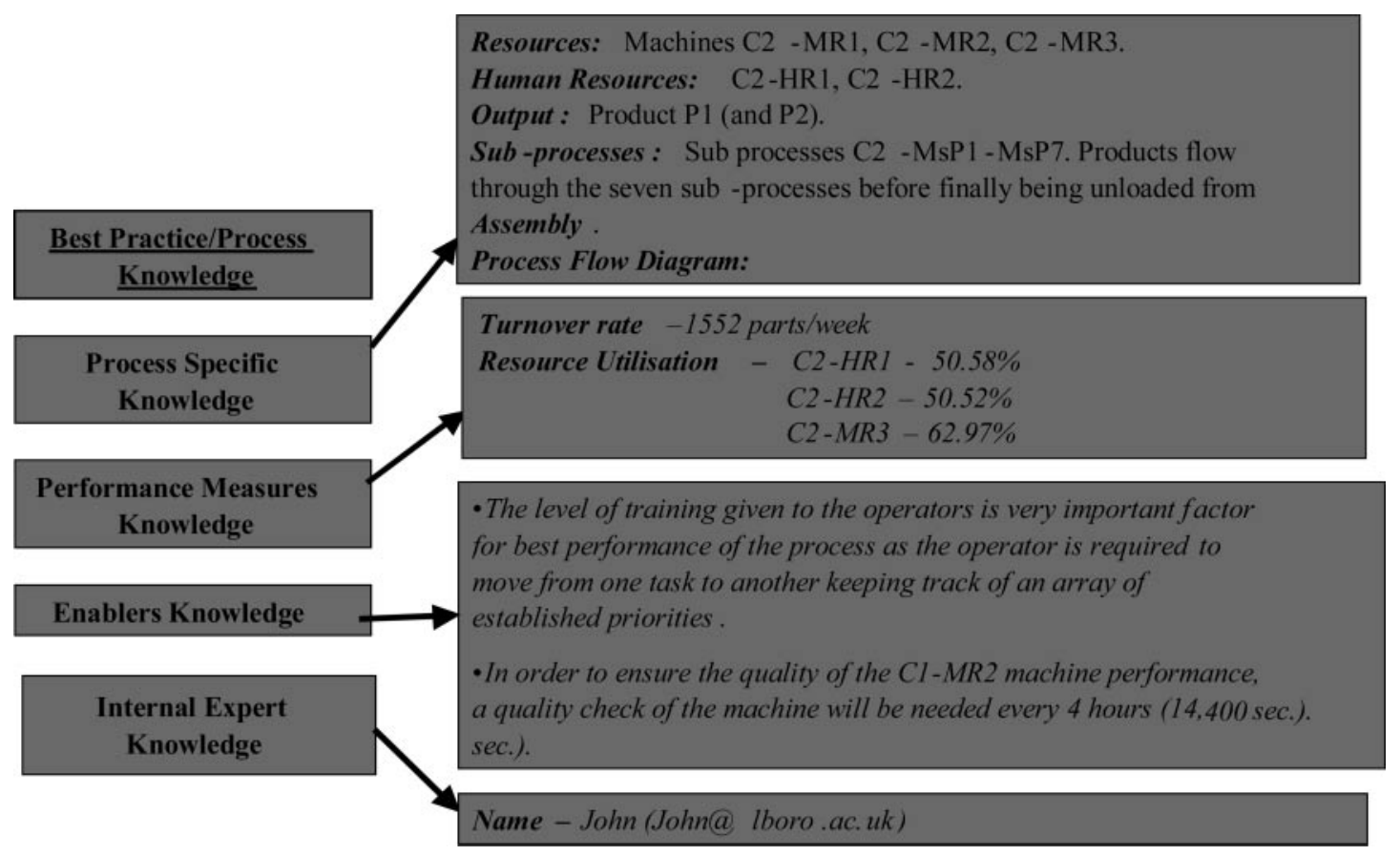

Fig. 8 Assembly 2 process elements

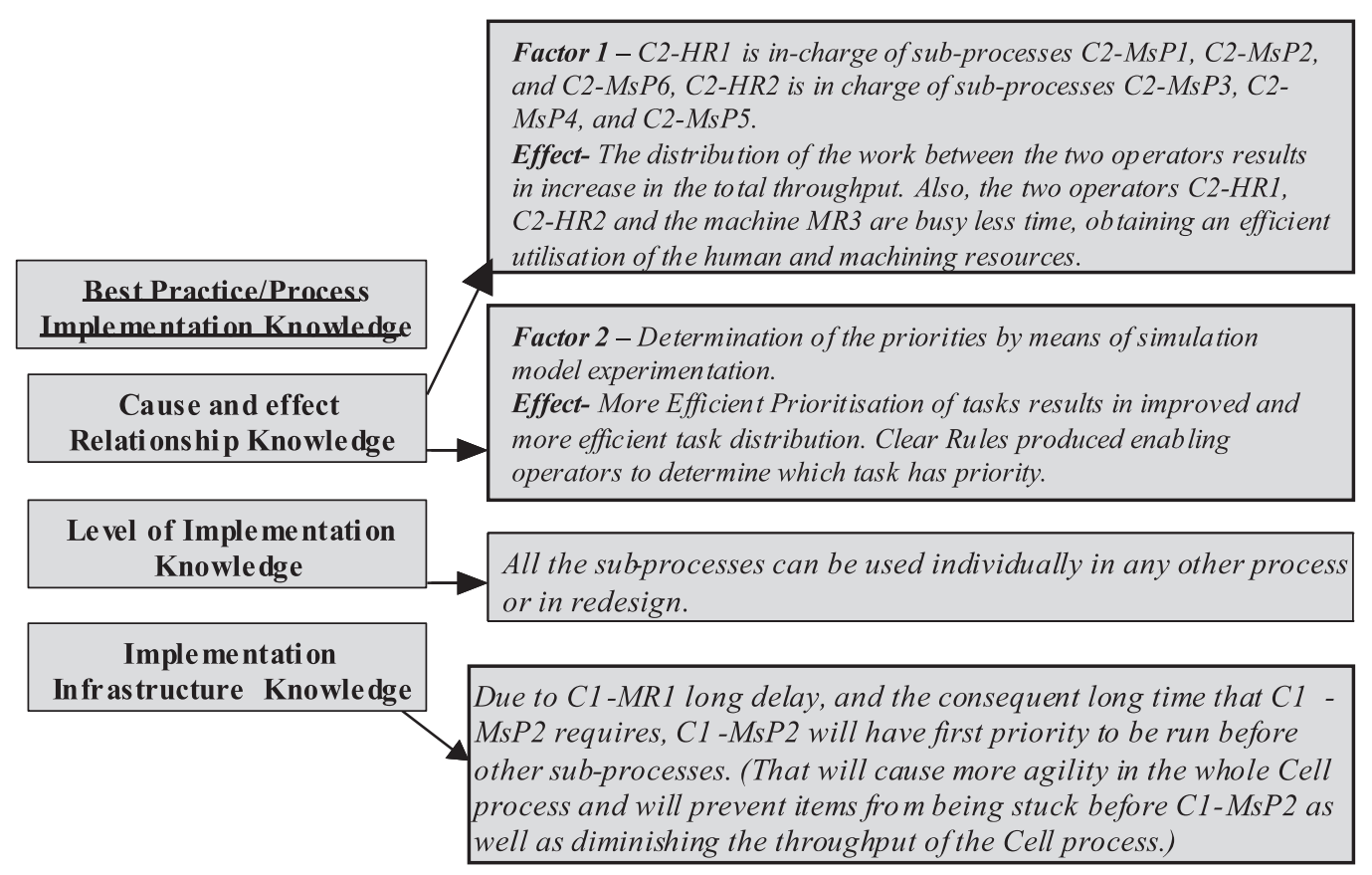

Fig. 9 Assembly 2 implementation elements

2. 'Best' is a moving target, and it is also situationspecific.

3. Certain practices are ones relevant to companies at particular points in their development, and thus for some companies individual best practices may not be appropriate at other points in time $[\mathbf{1 3}]$.

4. Best practices can be context-specific.
It is also evident from the literature that most of the best practice methodologies available today focus only on the identification of the best practices, rather than their application and reuse. Once best practices have been identified, companies encounter some difficulties regarding the collection of information that will make its transfer possible [30]. Industry requires support both in identifying the 


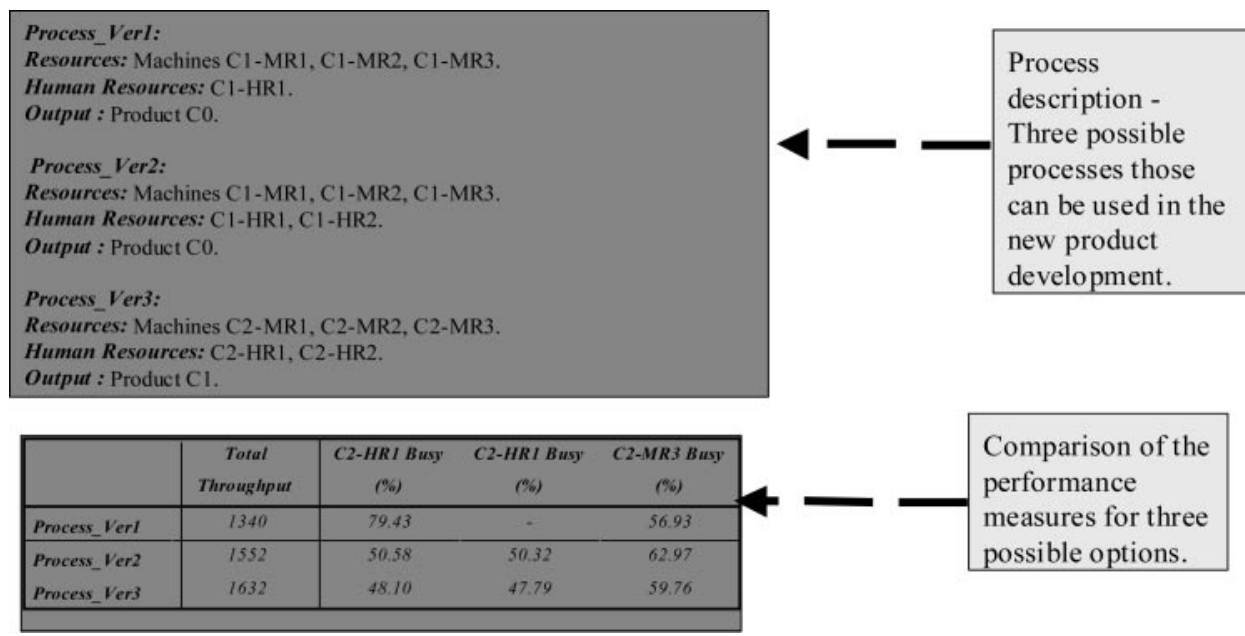

Fig. 10 Best practice comparison

most appropriate 'best practice' to meet its particular requirements and in understanding how the appropriate 'best practice' may be transferred. Although the literature shows that many companies have already identified and applied best practices to improve performance, it is also clear that very few companies have stored this knowledge effectively for future reuse. This research tries to address this issue and emphasizes that a knowledge base creation stage should be added to the current best practice methodologies. The methodology demonstrates how best practice knowledge could be represented so as to be more easily transferable.

\section{CONCLUSION}

Product design and development is informationintensive work. Capturing and reusing best practices forms an important part of the requirements of the next-generation product development. This paper presents a methodology for the identification and sharing of best practice knowledge. A structured approach to identifying and sharing best practice knowledge has been proposed in this paper. The proposed methodology encourages the adoption of best practices by providing the knowledge about the best process as well as their implementation elements. A best practice can be adopted if it:

(a) has a strong positive relationship with performance and objectives (partial or complete implementation);

(b) has no major adverse effects;

(c) has the necessary supporting practices in place for the desired practice to be implemented successfully.

The methodology also helps to identify highpriority, low-performance processes. Improving such high-priority process performance helps to formulate more best practices and better performance. The methodology proposed in this paper demonstrates how to identify what information and knowledge should go in the knowledge base, how knowledge should be classified, and how the knowledge base should be organized in order to implement the best practices. It also provides person-to-person linkage to support reuse of tacit knowledge. Finally, a case study example is presented in order to demonstrate the implementation of the proposed methodology. As this is an ongoing research project, validation has currently been restricted to the data acquired from one case study. As the methodology gains more recognition, validation will be sought using the research methods suggested by Laval et al. [31] and detailed case analysis as suggested by Fleischmann et al. [32].

\section{ACKNOWLEDGEMENTS}

This work is part of an ongoing research project entitled 'Knowledge representation and reuse for predictive design and manufacturing evaluation', and has been funded under EPSRC GR/ R64483/01.

\section{REFERENCES}

1 Ulrich, K. T. and Eppinger, S. D. Product design and development, 2003 (McGraw-Hill, Inc.).

2 Markus, M. L. Towards a theory of knowledge reuse: types of knowledge reuse situations and factors in reuse success. J. Managmt Inf. Systems, 2001, 18(1), 57-93.

3 Kogut, B. and Zander, U. Knowledge of the firm, combinative capabilities and replication of knowledge. Special issue: Management of technology. Orgn Sci., 1992, 3(3), 383-397. 
4 Connor, K. and Prahalad, C. K. A resource-based theory of the firm: knowledge versus opportunism. Orgn Sci., 1996, 7, 477-501.

5 Grant, R. M. Prospering in dynamically competitive environments: organizational capability as knowledge integration. Orgn Sci., 1996, 7, 375-388.

6 Teece, D. J., Pisano, G., and Shuen, A. Dynamic capabilities and strategic management. Strategic Managmt J., 1997, 18(7), 509-553.

7 American Productivity and Quality Center. What is benchmarking? APQC Report, Houston, Texas, 1997.

8 Siemieniuch, C. E. and Sinclair, M. A. Organisational aspects of knowledge lifecycle management in manufacturing. Int. J. Human-computer Stud., 1999, 51(3), 517-547.

9 Rezayat, M. Knowledge-based product development using XML and KCs. Computer-Aided Des., 2004, 32(5-6), 299-309.

10 Kermally, S. Effective knowledge management - a best practice blueprint, 2002 (John Wiley \& Sons, Chichester, UK)

11 Bogan, C. and English, M. Benchmarking for best practices: winning through innovative adaptation, 1994 (McGraw-Hill, New York).

12 Ramabadron, R., Dean, J. W. Jr, and Evans, J. R. Benchmarking and project management: a review and organizational model. Benchmarking for Qual. Managmt and Technol., 1997, 4, 47-58.

13 International Quality Study. Best practices report - an analysis of management practices that impact performance, 1993 (American Quality Foundation and Ernst \& Young, New York).

14 Johnson, C. Leveraging knowledge for operational excellence. J. Knowledge Managmt, 1997, 1(1), 50-55.

15 Camp, R. C. Benchmarking - the search for industry best practices that lead to superior performance, 1989 (ASQC Quality Press, Milwaukee, Wisconsin).

16 Heibeler, R., Kelly, T. B., and Ketteman, C. Best practices - building your business with customerfocused solutions, 1998 (Simon \& Schuster, New York).

17 Hughes, D. R. and Smart, P. A. The development and testing of a computer based tool to assist strategy formulation. In Proceedings of the Fourth International Conference on Factory 2000 - advanced factory automation, University of York, UK, 3-5 October 1994, pp. 312-17.
18 American Productivity and Quality Center. What is benchmarking?, 1994 (APQC, Houston, Texas).

19 Jarrar, Y. F. and Zairi, M. Best practice transfer for future competitiveness: a study of best practices. Total Qual. Managmt, 2000, 11(4-6), s734-s740.

20 American Productivity and Quality Center. Virtual collaboration: enabling project teams and communities: a consortium benchmarking study conducted by APQC Houston, Texas.

21 Zairi, M. and Whymark, J. The transfer of best practices: how to build a culture of benchmarking and continuous learning - part 1. Benchmarking: Int. J., 2000, 7(1), 62-78.

22 Zairi, M. and Whymark, J. The transfer of best practices: how to build a culture of benchmarking and continuous learning - part 2. Benchmarking: Int. J., 2000, 7(2), 146-167.

23 Davis, A. J. and Kochhar, A. K. Manufacturing best practices and performance studies: a critique. Int. J. Ops Prod. Managmt, 2002, 22(3), 289-305.

24 Bartlett, C. and Ghoshal, S. Changing the role of top management: beyond strategy to purpose. Harvard Bus. Rev., 1994, 79-88.

25 Boyle, T. A. Towards best management practices for implementing manufacturing flexibility. J. Mfg Technol. Managmt, 2006, 17(1), 6-21.

26 O'Leary, D. Using AI in knowledge management: knowledge bases and ontologies. IEEE Intell. Systems, 1998, 13(3), 34-39.

27 Davis, A. J. and Kochhar, A. K. A framework for the selection of best practices. Int. J. Ops Prod. Managmt, 1998, 20(10), 1203-1217.

28 Keegan, R. Benchmarking facts - a European perspective, 1998 (ColourBooks, Dublin).

29 Crow, K. Product development metrics. http://www. npd-solutions.com/pdmetrics.html (accessed on 15 May 2006).

30 Maire, J.-L., Bronet, V., and Pillet, M. A typology of 'best practices' for a benchmarking process. Benchmarking: Int. J., 2005, 12(1), 45-60.

31 Laval, C., Feyhl, M., and Kakouros, S. Hewlett-Packard combined OR and expert knowledge to design its supply chains. Interfaces, 2005, 35(3), 238-247.

32 Fleischmann, B., Ferber, S., and Henrich, P. Strategic planning of BMW's global production network. Interfaces, 2006, 36(3), 194-208. 